1）胃手術後の恵者は正常人に比へ，鉄の财収が 低下している。鉄の投与は経静脉的に行われること が望ましい。

2）特に胃点患者で，胃切除後長期生存例は低色 秦性の賁血が高率に現われるので，铁の投与を怠っ 、てはならない。

3） B-II法は B-I法に比べて明らか2に低色素性 の責血を招来する頻度が高いので，事情の詐すかぎ り，B-I法を行うべきである。

4）Castleの内因子は異体部並びに胃底部粘膜か
ら，より多く産出されろので，てのような点を充分 考虑して兽切除線を決定すべきである。B12 の吸収 に関しては噴閒側要全摘患者は胃全摘患者と同様に 管理されねばならない。

5）近年 B 12 の高単位投与の普及によって, 胃全 摘患者です，高色素性の悪性舴血をみることは殆ん どなくなったが，その反面，鉄欠乏を思わせる低色 素性頜血が展々みられるようになった。胃全摘及び 噴門側严全摘㭧者には B12 の投与と同時に鉄の経静 脉投与がぜひとも必要である。

\title{
胃切除術後の Oxyhyperglycemia
}

一一糖尿病との鑑別或はダンピング症候群との関連について——

日本バプテスト病院外科 京大 第二外科 戸 部 隆 吉

胃切除術後，原疾患は完全に治瘦し，何らの障碍 る残していないのにも拘わらず，一過性に高血糖を 呈し，糖尿を訴光る症例は注意して follow up して いると案外多く, 時に内科外来で糖尿病と㟝断治療 されているととすらある。これらの贯者に，ブドー 楉負荷試験を施行すると多くの場合，急激に血糖值 か上昇し，次いで急激に正常值に復する所謂Oxyhyperglycemia (Lawrence 1936) を呈する。この所 謂 Oxyhyperglycemia (oxy=sharp) は, Lawrence によって初めて記载されたもので，胃腸管からの吸 収の急速な場合に起ることが多く，糖尿を呈するも のの約 $7 \%$ 存し，全く無害であると報告されたが 当然起ると予想される胃切除術後患者には未だその 報告がみられない。私達は，胃切除術患者 100 例に 早朝空腹時ブドー糖50gを負莎し, Folin-Wua 法に より血糖を测定, Tes-Tapeにより尿煻を测定し た。

対照として，䏣石症手街前後の患者 110 例に同様 な方法でブドー糖を负荷し検索したが，胆石症の場 合には，術前術後を通じて diabetic pattern を星す るもの或は 2 時間值が高値を示し正常に復しないも のか非常に多いが，所謂 Oxyhyperglycemia を是 するものは非常に少なく，全体の1\%に充たない1。

胃切除術後には，全体の41\%に，所謂 Oxyhyperglycemia がみられ，特異な iatrogenic condition と考えられる。(私達の報告後, 同様な報告がみら

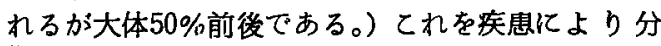

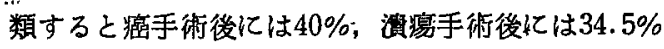

で特に大差はなく，手術術式により分類すると B I 術後には45\%，B II術後には40\%と大差は認められ ない。ところが年令分布により分類すると碓然とし た差が珰められ，50才以上では50.7\%に現われるの に50才以下では20\%しか現われない。40才以下では peak が $200 \mathrm{mg} / \mathrm{d} \ell$ を越える真の Oxyhyperglycemia は現われないのである゙)。(図 1) 従がって圈切除術 後の高血糖は Lawrence が指摘したように単に，

図 1

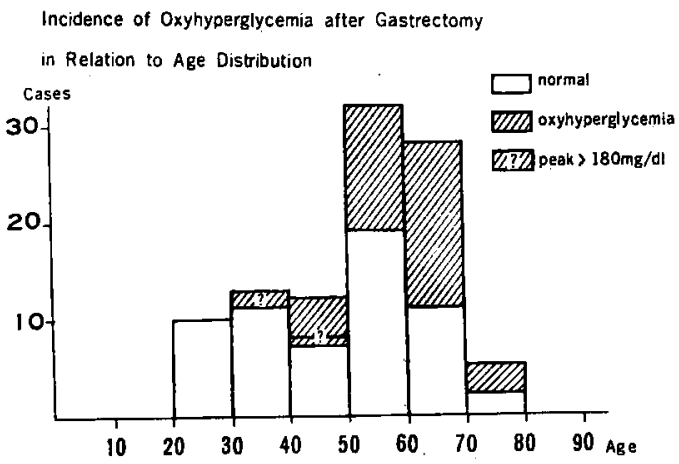

幽門部切除による急速な吸収によるものだけでなく 膵臓機能も大い関係していると考えられる。そこ で, 胃切除術時, 術前睌にG T T の異常値を示すも の或は老人，正常人，糖尿病靑者等約30例の膵臟バ イオプシー (surgical) を行ない病理組織学的検索 を行なったが, 共通して得られた老人の所見は，ラ 氏島 $\beta$ 細胞の脱顆粒と空胞変性（図 2)"で，糖尿病 にみられる $\beta$ 紐胞のヒアリン化等とは明.らかに区別 されるのである。このように，署切除術後には，約 


\section{㘣 2}

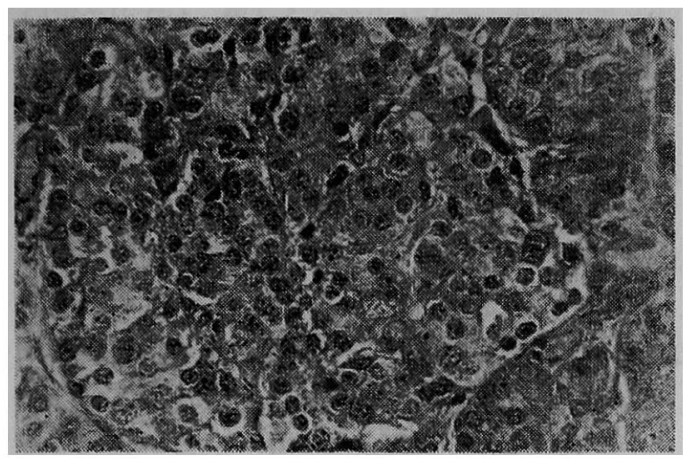

半数が，ブドー糖負荷により高血糖を呈し，尿糖を 来たすので, 特に老人では，食郋の種類により容易 に糖尿を来たし得るてとは理解出来るのである。

而し乍ら, 胃切除㫱後の高血糖は, 如何に長年に わたり糖永を呈していても，空腹時血糖値，血中コ レステロール值は正常筙围にあり, 又, 固形食を与 えた後の血精值は正常のことが多く，糖尿病とは明 らかに鑑別される。(图 3 )ただ，でく稀に私達の 症例で 2 例, 術前既化 Oxyhyperglycemia を有し た老人が，術後 1 年を経及間に diabetic pattern に 移行した例があり，糖尿病の遗伝歴を有し糖尿病発 生の素賽を有する人には，胃切除術は発症に対して 促進的であると考光, 術後の follow up と食郋指導 を行なうべきであると考元る。私達の症例で，糖尿 病の遗伝歴を有するものが5例みられたが全例が， 術後異常耐糖曲線を示した。常, 術前, 既に真性糖 尿病を有する思者では，術後，食餌コントロールは 困難になることが多く，特にインシニリン使用患者 では容易に低血糖を来たし得るので注意を要する。

次にダンピング症候群との関連について述べ。

最近 (1962), Johnson, Drapanas 等によって, 渴管䇒に分布するセロトニン $(5 \mathrm{HT})$ 産生細胞加ら のセロトニン $(5 \mathrm{HT})$ 遊離が，ダンピング症候群の 原因であるとする学説が提唱されている。てれは， 犬上位小腸に Witzel 氏腸瘦を作り，高張ブド一糖 液を急速に注入すると，七ロトニン $(5 \mathrm{HT})$ 産生細

\section{図 3 Differential Diagnosis}

\begin{tabular}{|l|l|c|}
\hline & $\begin{array}{c}\text { Hyperglycemia } \\
\text { after Gastrectomy }\end{array}$ & $\begin{array}{c}\text { Diabetes } \\
\text { mellitus }\end{array}$ \\
\hline Glycosuria & \# - & H + \\
GTT & oxyhyperglycemic & diabetic \\
FMT & almost normal & diabetic \\
FBS & normal & $\uparrow$ \\
Cholesterol & normal & $\uparrow$ \\
\hline
\end{tabular}

胞加らセロトニン (5 HT) が遊離され，門眽血中セ ロトニン $(5 \mathrm{HT})$ 浱度の上昇に一致してダンピング 症候群样症状が認められ，セロトニン拮抗用である Cyproheptadine hydrochloride (Periactine) 或は $\alpha$-Methyldopa (Aldomet) は, 実験的にも臨床的に もダンピング应候群に対して有効であるというので ある。胃切除術後, 液状物貝が, 胃から腸に急速に 流入し易い状態で，ブドー糖負荷試験を行ない，高 張糖液をのませることは，米国学派の人達が考案し たダンピング症群の実験モデルを逆に人間に行なっ ていることに他ならず，事実，胃切除術後のブドー 糖負荷試験時には，極めて高頻度に，悪心，頻脈， 冷汗等の不安症状を訴え，時に横卧しなければなら ないととすらあるす。而し乍ら，このような症状の 発現忧，高血糖とは全く無関係で若年者にも起り得 るのである。私達は，以前から蛍光法 (Falck,1962) を用い，セロトニン (5 HT) の組織化学的検索を行 はっているので，人胃腸管のセロトニン分布を明ら がにじ，更に高張ブドー糖液が，セロトニン $(5 \mathrm{H}$ T) を遊離させるか否かについて検索を行なった所 十二指腸或は空腸には，胃とは此較にならぬ程，大 量のセロトニン (5 HT) が分布し4, 更に, 高張糖 液は，完全にセロトニン (5 HT) を遊離させるとと を確認したのである5。生理食塩水では，セロト二 ン $(5 \mathrm{HT})$ は遊離されない。従がって，もしセロ卜 ニン $(5 \mathrm{HT})$ が, 米国学派の人達が考えるようにタ ンピング症群の原因であるとするならば，現在糖尿 病の診断に行なっているブドー糖負荷試験は，その ままダンピングテストとしても使用し得るわけであ ろ。従がって, 今後, 一定条件下, 例えば早朝空腹 時に一定量のブド一糖を与え，或は又，更に一定量 の固形食を与光，その反応を客稓的に把握するなら ば，諸家の統計のばらつきも減少すると思われる。 詳細は更に別紙䎲詳述する。

\section{文献}

1. 戸部隆吉, 好地街, 谷村弘, 黄秋雄: 胆石症術 前術後のG T T 亿ついて, 第10回日本糖永病学会発 表昭和 42 年 4 月。

2. Tobe, T. et al: Hyperglycemia after Gastrectomy as a Prediabetic State. Arch. Surg. 94, 836, 1967.

3. 木村忠司, 戸部隆吉：胃切除術後のダンピング 症候群。外科治療，14，204，1966。

4. Tobe, T., Tanaka, C., and Fuyiwara, M. : Distribution of Serotonin (5-Hydroxytryptamine) 
in the Human Gastrsintestinal Tract. Amer. J. Gastroentel. 46,34, 1966.

5. Tobe, T., Kimura, C. and Fuyiwara, M.: Role of 5-Hydroxytryptamine in the Dumping Syndrome after Gastrectomy. Histochemical Study. Ann, Surg. 165, 382, 1967.

\section{カプセル法による術後残胃の排出 \\ 機能に関する研究}

$\begin{array}{rrrr}\text { 慈恵医大 綿貫外科 } \text { ○丹羽 } & \text { 信善, 㭼 } & \text { 達 } \\ \text { 河井 啓三, 吉沢 } & \text { 良平, 伊礼 } & \text { 正剛 } \\ \text { 三枝 幹久, 高橋 } & \text { 惇, 里見 } & \text { 精英 } \\ \text { 松本 国光, 小野 裕弘, 綿貫 } & \text { 䓀 }\end{array}$

胃切除思者の残胃の排出機能検查には，レントゲ ン写真, レントゲンシネカメラ、バルーンによる内 王記録，平滑筋筋電図，ファイバースコープによる 吻合部の観察など，多くの方法が行われているがわ れわれは，いわゆるカプセル法による胃の排出機能 の検討を行っているので，残胃の排出についてカプ セル法の立場から報告する。

装置は国産の受信機と，電池式の温度測定用カプ セルを用いた。

あらかじめ患者にカプセルを巤下させておき，胃 内温度を測ってみると，負荷をあたえない限り，い つまでも $37^{\circ} \mathrm{C}$ 位を示しているので何か角荷をあた える必要がある。負荷の方法には, 温水, 或いは冷 水を服用させる方法があるが，冷水負荷の方が，温 度変化が大きいので，われわれは， $20^{\circ} \mathrm{C} ， 50 \mathrm{cc} の$ 令 水を与える方法を採用している。

健康人に，冷水を服用させると，胃内温度は急速 に下り，10〜15分で，ほはともの温度近くまで回復 する。

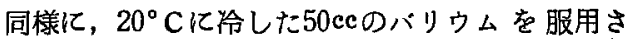
せて，レントゲン透視と同時に測定した胃内温度曲 線では，命水と同样にカーブは下降し，最下点 $\mathrm{A}$ 点 に羍し，やがて次第にもとの温度に回復してくる。 胃から12指腸への排出がない間は，てのカーブの回 復はゆるやかであるが，バリウム服用後，約 3 分B 点近くでカーブの勾配が変化し，回復が早くなる。 この曲線のB点におけるレントゲン写真でバリウム が胃から排出され始めている状態を示した。

カプセル法て測った冷水负荷胃内温度曲線は, 図 1のでとく，冷水負荷後，最る低い温度 $\mathrm{A}$ 点をすぎ ると，乙の曲線の勾配が変り B点からはゆるやかな 勾配になる。 $\mathrm{A}$ 点の温度を $\mathrm{T}_{1}$ とし，弧 $\mathrm{B} A$ を左の方
图 1 冷水負荷による胃内温度曲線

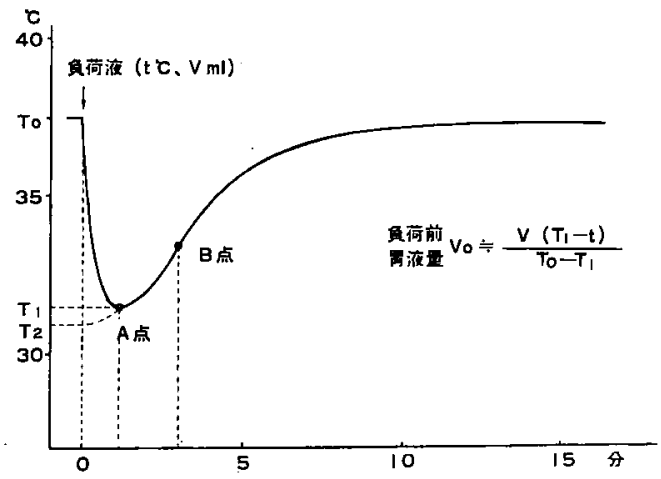

に延長して時間O点における垂直線との交点の温度

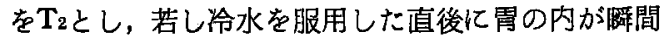
的に均等な温度になり，しかもカプセルにタイムう グがないとすれば，温度は $\mathrm{T}_{2}$ まで下降する管であ る。しかし，われわれの実測值蛙 $\mathrm{A}$ 点の $\mathrm{T}$ であり， T2とT1との差が大きくなけ扎ば，図1に示した数式 によって，冷水負荷前の胃液量を概算するととがて きる。

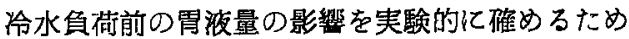
犬の喷門部々幽門部とを結帒して，冒の出入を止め 目街前の胃液量をいろいろ変えて，冷水負荷実駼を 行なってみると胃液量が少ないはど，温度の下降は 著明で, 回復曲線の勾配も急峻になっている。

胃からの排出による影響をしらべるため，同様に 犬で負荷前の胃液量を一定䎲して，温度曲線上のA 点をすきてから吸引片よって内容を排出させ，その 排出量をいろいろと変えてみると，排出量の多いは ぞ，曲線の勾配は大きくなり，冷水をあた元始める 々同時に一方加ら，すみや加排出させると，曲線 の勾配はさらに急峻となる。冷水直荷による胃内温 